\title{
IDENTIFIKASI KESULITAN GURU MATEMATIKA DALAM MENGIMPLEMENTASIKAN KURIKULUM 2013
}

\author{
Akhmad Faisal Hidayat \\ Universitas Batanghari Jambi \\ akhmad.faisal.hidayat@unbari.ac.id
}

\begin{abstract}
Abstrak: Perubahan kurikulum adalah suatu keniscayaan dalam rangka menyempurnakan kualitas dan mutu pendidikan. Konsekuensi dari suatu perubahan kurikulum ialah adanya perubahan prinsip yang diimplementasikan dalam pembelajaran. Perubahan prinsip dalam pembelajaran kurikulum 2013 berdampak pada perubahan tugas pokok serta kompetensi pedagogik dan profesional yang harus dikuasai oleh guru. Beberapa perubahan yang signifikan berpotensi menimbulkan kesulitan dalam penerapannya. Penelitian ini bertujuan untuk mengungkap kesulitan-kesulitan yang dialami guru matematika sekolah menengah pertama di kota Jambi, khususnya yang berkaitan dengan tugas pokok guru, meliputi proses merencanakan, melaksanakan dan mengevaluasi pembelajaran. Penelitian ini merupakan penelitian deskriptif eksploratif dengan menggunakan pendekatan kualitatif. Subjek dalam penelitian ini terdiri atas 17 orang guru matematika SMP yang dipilih menggunakan purposive sampling. Hasil penelitian menunjukkan terdapat kesulitan guru matematika dalam mengimplementasikan kurikulum 2013 yang berkaitan dengan tugas pokok guru, yaitu: (1) Tahap merencanakan pembelajaran, guru matematika kesulitan dalam merancang pembelajaran yang bervariasi, membuat keterkaitan tujuan pembelajaran dengan proses belajar peserta didik, menyusun silabus, merancang RPP yang sesuai dengan silabus serta merancang pembelajaran yang dapat memunculkan daya kreativitas dan kemampuan berfikir kritis peserta didik; (2) Tahap melaksanakan pembelajaran, guru matematika kesulitan dalam melakukan pembelajaran dan menggunakan teknik mengajar yang bervariasi, melaksanakan aktivitas pembelajaran sesuai dengan RPP, prinsip kurikulum serta terkait dengan konteks kehidupan sehari-hari, melakukan aktivitas pembelajaran yang menyenangkan, memberikan informasi baru sesuai dengan tingkat kemampuan peserta didik, serta memberikan kesempatan kepada peserta didik untuk bertanya dan mempraktekkan serta berinteraksi dengan peserta didik lainnya; (3) Tahap mengevaluasi pembelajaran, guru matematika kesulitan dalam menyusun alat penilaian yang sesuai dengan tujuan pembelajaran serta melaksanakan penilaian dengan berbagai teknik dan jenis penilaian. Selain itu, secara umum guru matematika juga mengalami kesulitan dalam menerapkan pembelajaran berbasis proyek.
\end{abstract}

Kata Kunci: Kesulitan, Implementasi, Kurikulum 2013.

Guru merupakan salah satu pihak yang mempunyai andil besar dalam perkembangan dunia pendidikan. Oleh karena itu, guru sebagai komponen yang paling menentukan dalam sistem pendidikan secara keseluruhan harus mendapat perhatian sentral, pertama, dan utama. Berbagai upaya perbaikan yang dilakukan untuk meningkatkan kualitas pendidikan tidak akan memberikan sumbangan yang signifikan tanpa didukung oleh guru yang berkualitas dan memiliki kompetensi. Dengan kata lain, perbaikan kualitas pendidikan harus berpangkal dari guru dan berujung pada guru.

Guru memiliki tugas dan fungsi yang sangat kompleks. Berdasarkan Permendikbud nomor 15 tahun 2018 ( Kemendikbud, 2018: 3-4 ) guru memiliki 3 tugas pokok yaitu merencanakan pembelajaran, melaksanakan pembelajaran, dan mengevaluasi pembelajaran. Dalam menjalankan ketiga tugas pokok tersebut, tentunya guru harus memiliki kompetensi. Sagala (2009:23) menyatakan bahwa kompetensi merupakan gabungan dari kemampuan, pengetahuan, kecakapan, sikap, sifat, pemahaman, apresiasi, dan harapan yang mendasari 
seseorang untuk berunjuk kerja dalam menjalankan tugas atau pekerjaan guna mencapai standar kualitas dalam pekerjaan nyata. Kompetensi digunakan sebagai acuan dalam mengukur kualifikasi dan profesionalitas seorang guru dalam menyelenggarakan pendidikan. Pada hakekatnya, ada 4 (empat) kompetensi yang harus dimiliki oleh seorang guru, yaitu kompetensi pedagogik, kompetensi kepribadian, kompetensi profesional, dan kompetensi sosial (Sagala, 2009: 31-41). Kompetensi-kompetensi tersebut merupakan modal dasar bagi seorang guru dalam membina dan mendidik peserta didik, sehingga tercapai mutu pendidikan yang menghasilkan peserta didik yang memiliki pengetahuan, sikap, dan keterampilan yang mumpuni.

Kompetensi guru yang bertalian langsung terhadap sistem pengelolaan pembelajaran ialah kompetensi pedagogik dan kompetensi profesional. Hal ini sebagaimana yang diterangkan oleh Trianto dan Titik (2007:71) bahwa kompetensi pedagogik merupakan kemampuan guru dalam mengelola pembelajaran peserta didik yang meliputi pemahaman terhadap peserta didik, perancangan dan pelaksanaan pembelajaran, evaluasi hasil belajar, dan pengembangan peserta didik untuk mengaktualisasikan berbagai potensi yang dimilikinya. Berdasarkan penjelasan tersebut, terlihat bahwa tugas pokok guru memiliki kaitan erat dengan kompetensi pedagogik yang harus dimilikinya, khususnya dalam mengimplementasikan kurikulum 2013.

Seiring dengan penyempurnaan Kurikulum Satuan Pendidikan (KTSP) menjadi Kurikulum 2013, terdapat beberapa prinsip pembelajaran yang mengalami perubahan paradigma sesuai dengan Standar Kompetensi Lulusan dan Standar Isi. Perubahanperubahan paradigma tersebut tentunya membuat para guru harus mampu beradaptasi, agar tugas pokok guru dapat terlaksana dengan baik sesuai dengan tuntutan kurikulum 2013.

Kurikulum 2013 seyogyanya telah mulai diberlakukan secara komprehensif diseluruh sekolah sejak tahun ajaran 2016/2017. Demikian halnya dengan sekolah-sekolah menengah pertama di kota Jambi, yang juga turut menerapkan kurikulum 2013 dalam kegiatan pembelajaran di sekolahnya. Namun berdasarkan hasil observasi yang dilakukan oleh tim peneliti pada beberapa sekolah menengah pertama di kota Jambi awal tahun 2018, diperoleh informasi bahwa beberapa guru masih belum sepenuhnya dapat beradaptasi dengan kurikulum ini. Akibatnya pembelajaran yang didesain hanya berlabel kurikulum 2013, tetapi prinsip-prinsip pembelajarannya masih jauh dari kurikulum 2013. Hal ini tentu merupakan indikasi adanya kesulitan yang dialami oleh guru untuk mengimplementasikan kurikulum 2013 dalam pembelajaran. Berdasarkan uraian permasalahan tersebut, maka tim peneliti tertarik untuk melakukan penelitian dengan judul "Identifikasi Kesulitan Guru Matematika dalam Mengimplementasikan Kurikulum 2013”

\section{METODE}

Penelitian ini merupakan penelitian deskriptif eksploratif dengan menggunakan pendekatan kualitatif. Hal ini dimaksudkan untuk mengetahui kesulitan-kesulitan yang dialami oleh guru dalam merencanakan, melaksanakan, dan mengevaluasi pembelajaran (dikaitkan dengan kompetensi pedagogik dan profesional), sesuai dengan prinsip kurikulum 2013.

Pemilihan subjek dan tempat penelitian menggunakan teknik Purposive Sampling, yakni pemilihan dengan pertimbangan tertentu. Beberapa hal yang digunakan oleh tim peneliti sebagai bahan pertimbangan dalam memilih subjek ialah: (1) Rayon sekolah yang berbeda; (2) Tahun penerapan kurikulum 2013 di sekolah tersebut; (3) Prestasi sekolah tersebut di bidang akademik, khususnya pada mata pelajaran matematika; (4) Guru mata pelajaran matematika. 
Penelitian ini dilakukan di tiga Sekolah Menengah Pertama yang mewakili 3 rayon berbeda. Subjek penelitian dalam penelitian ini terdiri dari 17 orang guru matematika.

Instrumen yang digunakan dalam penelitian ini meliputi instrumen utama dan instrumen pendukung. Instrumen Utama dalam penelitian ini ialah tim peneliti. Hal ini didasarkan pada peran peneliti dalam penelitian kualitatif yang meliputi penentuan fokus penelitian, subjek penelitian, pengumpulan data, analisis data serta membuat kesimpulan penelitian. Instrumen Pendukung dalam penelitian ini adalah angket, pedoman wawancara, alat rekam audio, dan lembar observasi. Angket yang diberikan berupa pertanyaan-pertanyaan yang mengarah pada kesulitan guru dalam mengimplemetasikan kurikulum 2013 dengan mengacu pada tiga tugas pokok guru yaitu merencanakan, melaksanakan, dan mengevaluasi pembelajaran dalam kaitannya dengan kompetensi pedagogik dan profesional guru. Selain itu, angket juga mengacu pada prinsip-prinsip kurikulum 2013. Wawancara yang dilakukan pada penelitian ini merupakan wawancara semi terstruktur berdasarkan jawaban angket subjek penelitian. Wawancara dilakukan untuk memperjelas jawaban subjek penelitian. Oleh karena itu, pedoman wawancara hanya memuat pertanyaan pokok dan pelaksanaan di lapangan tergatung pada hassil angket dan observasi di lapangan. Observasi dilakukan untuk melihat pembelajaran yang dilakukan oleh beberapa subjek penelitian, sehingga peneliti mendapat informasi lebih akurat terkait penerapan kurikulum 2013 di lapangan.

Pengumpulan data dalam penelitian ini diawali dengan menetapkan lokasi penelitian dengan mewawancarai beberapa kenalan guru terkait dengan rayon dan prestasi sekolah. Dari wawancara tersebut, peneliti memperoleh data terdapat 6 rayon SMP di lingkup kota jambi. Dari 6 rayon tersebut peneliti hanya memilih 3 rayon dan menentukan 3 Sekolah Menengah Pertama di Lingkup Kota Jambi. Setiap sekolah mewakili masing-masing rayon. Selanjutnya peneliti memberikan angket kepada setiap guru matematika yang ada di 3 sekolah yang telah ditentukan. Selain angket, subjek penelitian di wawancarai terkait dengan jawaban angket. Selain itu, peneliti juga melakukan observasi kelas untuk melihat langsung kegiatan pembelajaran di kelas.

Teknik analisis data dalam penelitian ini mengacu pada teknik analisis data yang di paparkan oleh Miles, Huberman \& Saldana (2014) yang meliputi kegiatan kondensasi data (data condensation), penyajian data (data display) dan gambaran serta verifikasi kesimpulan (drawing and verifying conclusions). Temuan yang diperoleh dalam penelitian ini akan divalidasi dengan menggunakan triangulasi metode, yaitu berupa hasil angket, wawancara, dan observasi ketika pembelajaran berlangsung serta triangulasi sumber.

\section{HASIL DAN PEMBAHASAN}

Berdasarkan hasil angket terhadap 17 guru matematika yang mengajar di tiga Sekolah Menengah Pertama di Kota Jambi, diperoleh data sebagai berikut.

Tabel 1. Hasil Angket Identifikasi Kesulitan Guru

\begin{tabular}{|c|c|c|}
\hline \multirow[b]{2}{*}{$\begin{array}{c}\text { Tugas Pokok Guru dan Kompetensi Guru (Pedagogik dan } \\
\text { Profesional) }\end{array}$} & \multicolumn{2}{|c|}{ Keterangan } \\
\hline & $\begin{array}{l}\text { Mengalami } \\
\text { kesulitan }\end{array}$ & $\begin{array}{l}\text { Tidak mengalami } \\
\text { kesulitan }\end{array}$ \\
\hline \multicolumn{3}{|l|}{$\begin{array}{l}\text { A. Merencanakan Pembelajaran } \\
\text { 1. Pedagogik }\end{array}$} \\
\hline a. Identifikasi karakteristik peserta didik & $12 \%$ & $88 \%$ \\
\hline b. Pembelajaran yang bervariasi & $82 \%$ & $18 \%$ \\
\hline c. Keterkaitan tujuan pembelajaran dengan proses belajar peserta didik & $65 \%$ & $35 \%$ \\
\hline d. Menyusun silabus & $65 \%$ & $35 \%$ \\
\hline
\end{tabular}




\begin{tabular}{|c|c|c|}
\hline \multirow{2}{*}{$\begin{array}{l}\begin{array}{c}\text { Tugas Pokok Guru dan Kompetensi Guru (Pedagogik dan } \\
\text { Profesional) }\end{array} \\
\end{array}$} & \multicolumn{2}{|c|}{ Keterangan } \\
\hline & $\begin{array}{c}\text { Mengalami } \\
\text { kesulitan }\end{array}$ & $\begin{array}{c}\text { Tidak mengalami } \\
\text { kesulitan }\end{array}$ \\
\hline e. Merancang RPP yang sesuai dengan Silabus dan kurikulum 2013 & $65 \%$ & $35 \%$ \\
\hline f. Urutan materi pelajaran sesuai dengan tujuan pembelajaran & $12 \%$ & $88 \%$ \\
\hline g. Pertimbangan dalam memilih materi pembelajaran & $12 \%$ & $88 \%$ \\
\hline $\begin{array}{l}\text { h. Pembelajaran yang memunculkan daya kreativitas dan kemampuan } \\
\text { berfikir kritis }\end{array}$ & $94 \%$ & $6 \%$ \\
\hline \multicolumn{3}{|l|}{ 2. Profesional } \\
\hline a. Memetakan KI dan KD untuk mata pelajaran yang diampunya & $65 \%$ & $35 \%$ \\
\hline $\begin{array}{l}\text { b. Menyusun materi dan RPP yang berisi materi yang tepat dan } \\
\text { mutakhir }\end{array}$ & $65 \%$ & $35 \%$ \\
\hline c. Memanfaatkan TIK & $82 \%$ & $18 \%$ \\
\hline \multicolumn{3}{|l|}{ B. Melaksanakan Pembelajaran } \\
\hline \multicolumn{3}{|l|}{ 1. Pedagogik } \\
\hline a. Pembelajaran yang bervariasi & $82 \%$ & $18 \%$ \\
\hline b. Identifikasi kemampuan awal peserta didik & $12 \%$ & $88 \%$ \\
\hline c. Teknik mengajar yang bervariasi & $76 \%$ & $24 \%$ \\
\hline d. Menggunakan respon peserta didik untuk perbaikan RPP & $18 \%$ & $82 \%$ \\
\hline e. Melaksanakan aktivitas pembelajaran sesuai dengan RPP & $65 \%$ & $35 \%$ \\
\hline f. Aktivitas pembelajaran yang menyenangkan & $65 \%$ & $35 \%$ \\
\hline $\begin{array}{l}\text { g. Memberikan informasi baru sesuai dengan tingkat kemampuan } \\
\text { peserta didik }\end{array}$ & $65 \%$ & $35 \%$ \\
\hline h. Menghadapi kesalahan sebagai suatu bagian proses pembelajaran & $24 \%$ & $76 \%$ \\
\hline $\begin{array}{l}\text { i. Aktivitas pembelajaran sesuai dengan isi kurikulum dan terkait } \\
\text { dengan konteks kehidupan sehari-hari }\end{array}$ & $82 \%$ & $18 \%$ \\
\hline $\begin{array}{l}\text { j. Memberikan banyak kesempatan kepada peserta didik untuk } \\
\text { bertanya, mempraktekkan dan berinteraksi dengan peserta didik lain }\end{array}$ & $53 \%$ & $47 \%$ \\
\hline k. Menggunakan alat bantu mengajar dan TIK & $82 \%$ & $18 \%$ \\
\hline $\begin{array}{l}\text { 1. Pembelajaran yang memunculkan daya kreativitas dan kemampuan } \\
\text { berfikir kritis }\end{array}$ & $94 \%$ & $6 \%$ \\
\hline \multicolumn{3}{|l|}{ 2. Profesional } \\
\hline a. Menyertakan informasi mutakhir pada pembelajaran & $65 \%$ & $35 \%$ \\
\hline b. Penyusunan dan penguasaan materi & $35 \%$ & $65 \%$ \\
\hline \multicolumn{3}{|l|}{ C. Mengevaluasi Pembelajaran } \\
\hline \multicolumn{3}{|l|}{ 1. Pedagogik } \\
\hline a. Menyusun alat penilaian yang sesuai dengan tujuan pembelajaran & $65 \%$ & $35 \%$ \\
\hline b. Melaksanakan penilaian dengan berbagai teknik dan jenis penilaian & $65 \%$ & $35 \%$ \\
\hline c. Menganalisis hasil pembelajaran & $24 \%$ & $76 \%$ \\
\hline d. Memanfaatkan saran dari peserta didik dan merefleksinya & $18 \%$ & $82 \%$ \\
\hline e. Memanfaatkan hasil penilaian untuk merancang RPP selanjutnya & $35 \%$ & $65 \%$ \\
\hline 2. Profesional & & \\
\hline $\begin{array}{l}\text { a. Menggunakan pengalaman diklat untuk merancang penilaian } \\
\text { pembelajaran }\end{array}$ & $35 \%$ & $65 \%$ \\
\hline
\end{tabular}

Berdasarkan tabel 1 di atas, terlihat bahwa terdapat beberapa kesulitan yang dialami guru dalam menjalankan tugas pokoknya sesuai dengan tuntutan kurikulum 2013. Berikut pembahasan hasil penelitian berdasarkan wawancara dan observasi yang dikaitkan dengan hasil angket pada tabel 1 .

\section{A. Merencanakan pembelajaran}

Umumnya guru mampu mengidentifikasi karakteristik belajar peserta didik, hal ini terlihat dari hasil angket dan wawancara yang dilakukan peneliti bahwa guru dapat menjelaskan kondisi siswanya di kelas. Selain itu, pada umumnya guru juga tidak kesulitan dalam memilih materi pembelajaran dan dapat menyesuaikan urutan materi pembelajaran 
dengan tujuan pembelajaran. Hal ini disebabkan pengalaman mengajar dan disediakannya buku guru oleh pemerintah, sehingga dapat menuntun guru untuk menyusun materi pembelajaran.

Beberapa kesulitan yang umumnya dialami oleh guru dalam merencanakan pembelajaran yaitu merancang pembelajaran yang bervariasi, membuat keterkaitan tujuan pembelajaran dengan proses belajar peserta didik, menyusun silabus, merancang RPP yang sesuai dengan silabus serta pembelajaran yang memunculkan daya kreativitas dan kemampuan berfikir kritis. Kesulitan dalam merancang pembelajaran yang bervariasi yaitu terkait ide dalam merancang aktivitas pembelajaran tersebut. Pembelajaran yang bervariasi diharapkan dapat memberi kesempatan kepada peserta didik dalam menguasai materi pembelajaran sesuai usia dan kemampuan belajarnya, sehingga pembelajaran tersebut dapat membuat peserta didik tertarik untuk mencari tahu. Namun umumnya, aktivitas pembelajaran yang dirancang oleh guru cenderung monoton dan kurang bervariasi. Kegiatan mengamati yang dirancang guru, terkadang hanya membaca materi pada buku siswa. Selain itu, kegiatan mengumpulkan data yang dirancang oleh guru juga hanya mengumpulkan informasi yang ada pada buku siswa. Sehingga, membuat peserta didik kurang tertarik untuk mencari tahu tentang materi yang dipelajari.

Pada penyusunan silabus, umumnya guru mengalami kesulitan dalam menyusun Indikator Pencapaian Kompetensi (IPK) yang diturunkan dari Kompetensi Dasar (KD) yang dituju. Ada beberapa guru kesulitan menurunkan IPK dari KD 3 dan KD 4, sehingga tingkat tercapai pembelajaran pada KD tersebut. Selain itu, guru juga kesulitan merancang kegiatan pembelajaran yang menggunakan pendekatan saintifik, serta menyediakan bahan amatan yang membuat peserta didik tertarik untuk mengamati, bertanya, mengumpulkan data, dan mengasosiasi data. Kesulitan-kesulitan tersebut mengakibatkan guru hanya menggunakan silabus yang sudah ada terdahulu, baik yang diperoleh melalui internet maupun yang sudah banyak beredar dikalangan para guru. Kondisi ini juga tidak jauh berbeda dalam penyusunan RPP.

Kesulitan dalam penyusunan silabus mengakibatkan guru cenderung merancang RPP yang tidak sesuai dengan silabus, khususnya terkait dengan Indikator Pencapaian Kompetensi (IPK), aktivitas pembelajaran, teknik penilaian, dan alokasi waktu. Umumnya guru menggunakan silabus yang sudah ada tanpa memperhatikan keterkaitan silabus dan RPP yang dibuat. Selain itu, guru juga mengalami kesulitan dalam menyusun RPP. Kesulitan tersebut antara lain: (a) merancang pembelajaran yang dapat membuat peserta didik tertarik untuk mencari tahu; (b) menyusun LKPD yang sesuai dengan prinsip kurikulum 2013; (c) merancang alat peraga yang dapat digunakan untuk menanamkan konsep pada peserta didik; (d) menyiapkan bahan amatan yang dapat membuat siswa tertarik mencari tahu, (e) merancang aktivitas pembelajaran yang menggunakan pendekatan saintifik, khususnya pada kegiatan mengamati, mengumpulkan data, dan mengasosiasikan; (f) merancang aktivitas pembelajaran berbasis proyek. Hal ini dikarenakan tidak semua materi pelajaran matematika dapat dirancang dalam aktivitas pembelajaran berbasis proyek serta menggunakan bahan amatan yang menarik. Selain itu, beberapa guru belum mengetahui cara menyusun LKPD yang baik sesuai dengan prinsip-prinsip dalam kurikulum 2013.

Kesulitan guru selanjutnya ialah dalam merancang pembelajaran yang memunculkan daya kreativitas serta kemampuan berfikir kritis. Hal ini disebabkan kurangnya pengalaman diklat guru tentang pembelajaran yang dapat memunculkan daya kreativitas dan kemampuan berfikir kritis. Sangat jarang guru yang mendapatkan diklat tersebut, 
sehingga guru kesulitan untuk mencari ide pembelajaran yang sesuai dengan materi. Selain itu, materi yang padat dan alokasi waktu yang tidak cukup mengakibatkan guru cenderung merancang pembelajaran yang berorientasi pada ketuntasan materi yang diajarkan. Sehingga sangat sulit untuk mengembangkan pembelajaran yang dapat memunculkan daya kreativitas serta kemampuan berfikir kritis siswa.

\section{B. Melaksanakan pembelajaran}

Umumnya guru dapat mengidentifikasi kemampuan awal peserta didik. Hal ini terlihat dari hasil angket, wawancara, dan observasi yang dilakukan oleh peneliti. Sebelum memulai materi baru, umumnya guru melakukan kegiatan apersepsi yaitu mengecek kemampuan awal peserta didik. Hal ini dilakukan guru, agar peserta didik mengingat kembali materi yang pernah dipelajari sebelumnya dan mempersiapkan peserta didik untuk mempelajari materi baru. Selain itu, guru dapat menggunakan respon peserta didik untuk perbaikan RPP. Meskipun terkadang guru hanya memperbaiki pembelajaran pada kelas berikutnya, tanpa mengubah RPP yang sudah dibuat sebelumnya. Berdasarkan observasi, dalam melaksanakan pembelajaran terlihat secara umum guru dapat mengelola daan menjadikan kesalahan peserta didik sebagai suatu bagian dari proses pembelajaran. Kesalahan yang dilakukan peserta didik digunakan sebagai bahan diskusi, sehingga membuat peserta didik dapat berpikir mengenai materi yang benar.

Beberapa kesulitan yang umumnya dialami oleh guru dalam melaksanakan pembelajaran sangat berkaitan erat dengan kesulitan guru dalam merencanakan pembelajaran. Sehingga, kesulitan yang dihadapi pada perencanaan akan dialami juga pada pelaksanaan pembelajaran. Adapun kesulitan guru dalam melaksanakan pembelajaran, yaitu pembelajaran yang bervariasi, teknik mengajar yang bervariasi, melaksanakan aktivitas pembelajaran sesuai dengan RPP, aktivitas pembelajaran yang menyenangkan, memberikan informasi baru sesuai dengan tingkat kemampuan peserta didik, aktivitas pembelajaran sesuai dengan isi kurikulum dan terkait dengan konteks kehidupan sehari-hari, memberikan banyak kesempatan kepada peserta didik untuk bertanya dan mempraktekkan serta berinteraksi dengan peserta didik lain.

Dalam melakukan pembelajaran dengan teknik mengajar yang bervariasi ini, guru kesulitan dalam menghadapi kelas besar, guru kewalahan membimbing pembelajaran berkelompok yang biasanya terdiri dari 8 kelompok dengan masing-masing kelompok beranggotakan 4 orang. Selain itu, guru membutuhkan waktu yang lebih lama dalam menerapkan beberapa model pembelajaran yang direkomendasikan kurikulum 2013 dibandingkan dengan menggunakan pembelajaran yang konvensional. Sehingga ada kecenderungan ketika guru merasa kehabian waktu dan lebih berorientasi pada ketuntasan materi yang akan diajarkan, maka pembelajaran konvensional menjadi solusi akhir.

Pada pelaksanaan pembelajaran, guru cenderung tidak dapat melakukan aktivitas pembelajaran sesuai dengan RPP yang telah dirancang. Selain itu, guru juga mengalami kesulitan dalam melaksanakan aktivitas pembelajaran yang sesuai dengan prinsip kurikulum 2013. Hal ini disebabkan beberapa hal, yaitu: (1) respon peserta didik yang terkadang tidak sesuai dengan ekspektasi guru; (2) kurangnya budaya membaca peserta didik; (3) sulit membuat peserta didik mengerti operasi-operasi matematika dengan menggunakan sumber belajar selain guru; (4) kemampuan matematika dasar peserta didik yang rendah; (4) kesalahan dalam menganalisis kemampuan rata-rata peserta didik. Kesalahan ini mengakibatkan latihan-latihan yang diberikan sebagai scafolder dalam memahami suatu materi, ternyata justru menjadi beban belajar bagi peserta didik karena 
dianggap latihan-latihan tersebut sangat sulit. Dalam aktivitas pembelajaran berkelompok, tidak semua kelompok memperoleh kesempatan dalam mempresentasikan hasil diskusi mereka. Hal ini disebabkan oleh keterbatasan waktu serta masih rendahnya antusiasme peserta didik dalam aktivitas tersebut.

Dalam melaksanakan aktivitas pembelajaran yang menyenangkan serta berkaitan dengan konteks kehidupan sehari-hari, guru umumnya mengalami kesulitan. Hal ini dikarenakan beberapa materi pelajaran matematika yang cenderung abstrak. Guru tidak hanya mengalami kesulitan dalam merancang pembelajaran, tetapi juga dalam melaksanakan pembelajaran yang menyenangkan bagi peserta didik. Selain itu, keterbatasan pengetahuan guru juga mengakibatkan kesulitan dalam memberikan informasi baru yang sesuai dengan tingkat kemampuan peserta didik.

Kesulitan yang dialami guru juga terkait beberapa materi pembelajaran matematika yang cenderung abstrak. Alternatif solusi untuk mengatasi masalah ini salah satunya adalah alat peraga atau media pembelajaran yang dapat membantu peserta didik memahami ide abstrak matematika agar menjadi lebih konkret. Namun, keterbatasan ide dan kemampuan guru menyebabkan guru belum dapat menciptakan beberapa alat peraga yang dibutuhkan. Hal ini berakibat pada kurangnya kesempatan peserta didik dalam menggunakan alat peraga matematika. Walaupun demikian, umumnya guru selalu memberikan kesempatan kepada peserta didik untuk bertanya mengenai materi pembelajaran dan memberikan kesempatan peserta didik untuk berdiskusi dalam menyelesaikan masalah matematika.

\section{Mengevaluasi pembelajaran}

Dalam melakukan evaluasi pembelajaran, umumnya guru mampu menganalisis hasil pembelajaran yang telah dilakukan, memanfaatkan saran dari peserta didik dan merefleksinya, memanfaatkan hasil penilaian untuk merancang pembelajaran selanjutnya. Hal ini terlihat dari hasil angket, wawancara, dan observasi yang dilakukan oleh peneliti. Setelah melaksanakan penilaian, guru mampu untuk memilah materi yang sulit, sehingga perlu dilakukan remedial. Selain itu, guru biasanya menggunakan pengalaman pada tahun sebelumnya untuk memperbaiki pembelajaran pada materi yang sama di tahun berikutnya. Meskipun demikian, perbaikan yang dilakukan guru biasanya hanya pada pelaksanaanya saja, tanpa merubah RPP yang sudah terlanjur dibuat.

Beberapa kesulitan yang dialami guru dalam mengevaluasi pembelajaran yaitu menyusun alat penilaian yang sesuai dengan tujuan pembelajaran serta melaksanakan penilaian dengan berbagai teknik dan jenis penilaian. Kesulitan guru pada penyusunan alat penilaian ini sering terjadi pada penilaian kompetensi dasar (KD) keterampilan, sedangkan pada KD pengetahuan guru biasanya tidak mengalami kesulitan. Kesulitan guru pada penilaian keterampilan yang banyak dikeluhkan terkait penyusunan instrumen penilaian yang sesuai. Keterbatasan pemahaman guru terkait penilaian keterampilan berakibat beberapa guru cenderung mengasosiasikan penilaian keterampilan sebagai penilaian praktikum, sehingga dianggap terpisah dengan penilaian pengetahuan. Padahal dalam pembelajaran matematika, penilaian keterampilan lebih ditekankan pada penilaian unjuk kerja, baik secara fisik, maupun mental. Hal ini terlihat dari hasil wawancara dan observasi yang menunjukkan bahwa guru umumnya secara tidak sadar telah melakukan penilaian keterampilan yang sudah terintegrasi pada soal ulangan harian, namun hanya dianggap sebagai bagian dari penilaian pengetahuan. Penilaian keterampilan yang berorientasi pada aktivitas fisik seperti melukis segitiga, membagi ruas garis, membuat dan mengukur sudut, membuat grafik, dan masih banyak lagi. Sedangkan penilaian keterampilan yang 
berorientasi pada aktivitas mental seperti kegiatan memecahkan masalah (problem solving).

Kesulitan lainnya yang banyak dialami oleh guru matematika ialah merancang dan melaksanakan aktivitas pembelajaran berbasis proyek. Padahal pembelajaran berbasis proyek merupakan salah satu model pembelajaran yang direkomendasikan pada penerapan kurikulum 2013. Berdasarkan hasil wawancara diperoleh informasi bahwa umumnya guru merasa kesulitan dalam merancang, melaksanakan serta melakukan penilaian pada pembelajaran berbasis proyek, dikarenakan kuranganya pengalaman dan pemahaman guru terkait model pembelajaran tersebut.

\section{KESIMPULAN}

Berdasarkan hasil penelitian dan pembahasan, maka dapat disimpulkan bahwa kesulitan guru dalam mengimplementasikan kurikulum 2013 terkait dengan tiga pokok tugas guru dan kompetensi guru (padagogik dan profesional) adalah sebagai berikut: (1) Tahap merencanakan pembelajaran, guru matematika cenderung kesulitan dalam merancang pembelajaran yang bervariasi, membuat keterkaitan tujuan pembelajaran dengan proses belajar peserta didik, menyusun silabus, merancang RPP yang sesuai dengan silabus serta merancang pembelajaran yang dapat memunculkan daya kreativitas dan kemampuan berfikir kritis peserta didik; (2) Tahap melaksanakan pembelajaran, guru matematika cenderung kesulitan dalam melakukan pembelajaran dan menggunakan teknik mengajar yang bervariasi, melaksanakan aktivitas pembelajaran sesuai dengan RPP, prinsip kurikulum serta terkait dengan konteks kehidupan sehari-hari,melakukan aktivitas pembelajaran yang menyenangkan, memberikan informasi baru sesuai dengan tingkat kemampuan peserta didik, serta memberikan kesempatan kepada peserta didik untuk bertanya dan mempraktekkan serta berinteraksi dengan peserta didik lainnya. (3) Tahap mengevaluasi pembelajaran, guru matematika cenderung kesulitan dalam menyusun alat penilaian yang sesuai dengan tujuan pembelajaran serta melaksanakan penilaian dengan berbagai teknik dan jenis penilaian. Selain itu, secara umum guru juga mengalami kesulitan dalam menerapkan pembelajaran berbasis proyek

\section{REKOMENDASI PENELITIAN}

Berdasarkan temuan penelitian di atas, peneliti mengajukan beberapa rekomendasi dalam mengatasi kesulitan guru matematika dalam mengimplementasikan kurikulum 2013.

1. Bagi pemerintah, perlu diadakan diklat yang lebih mendalam mengenai penerapan kurikulum 2013, khususunya diklat yang secara spesifik melatih keterampilan guru dalam merancang perangkat pembelajaran yang menggunakan pendekatan saintifik, pembelajaran berbasis masalah, dan pembelajaran berbasis proyek.

2. Bagi Sekolah, perlu diadakan in house training untuk meningkatkan kualifikasi guru dalam merancang perangkat pembelajaran yang menggunakan pendekatan saintifik, pembelajaran berbasis masalah, dan pembelajaran berbasis proyek.

3. Bagi Guru, perlu meningkatkan kemampuan pedagogik dan keprofesionalan, tidak hanya melalui diklat yang diadakan pemerintah ataupun sekolah, namun bisa dilakukan dalam Musyawarah Guru Mata Pelajaran (MGMP) serta diklat online yang dapat meningkatkan kualifikasi guru tidak hanya dalam merancang pembelajaran tetapi juga dalam penggunaan TIK yang mengarah kepada pembelajaran 4.0. 
50 AKSIOMA, Volume 9 Nomor 1, Maret 2020

\section{REFERENSI}

Djamarah, Syaiful Bahri. 2008. Prestasi Belajar dan Kompetensi Guru. Surabaya: Usaha Nasional.

Kemendikbud. 2016. Permendikbud No. 22 tentang Standar Proses Pendidikan dasar dan Menengah. Jakarta: Kemendikbud.

Kemendikbud. 2018. Permendikbud No. 15 tahun 2018 tentang Pemenuhn Beban Kerja Guru, Kepala Sekolah, dan Pengawas. Jakarta: Kemendikbud.

Miles, M. B., Huberman, A. M., \& Saldana J. 2014. Qualitative Data Analysis: A Methods Sourcebook $3^{\text {rd }}$ Edition. California: Sage

Mulyasa. 2008. Standar Kompetensi dan Sertifikasi Guru. Bandung: PT. Remaja Rosdakarya Offset.

Sagala, S. 2009. Kemampuan Profesional Guru dan Tenaga Kependidikan. Bandung: CV. Alfabeta.

Slameto. 2003. Belajar dan Faktor-Faktor yang Mempengaruhinya. Jakarta: Rineka Cipta.

Trianto dan Titik T. T. 2007. Sertifikasi Guru dan Upaya Peningkatan Kualifikasi, Kompetensi, dan Kesejahteraan: Jakarta: Prestasi Pustaka Publisher.

Uno, Hamzah B. 2011. Profesi Kependidikan: Problema, Solusi, dan Reformasi Pendidikan di Indonesia. Jakarta: PT. Bumi Aksara.

Yamin, Martinis. 2010. Strategi Pembelajaran Berbasis Kompetensi. Jakarta: Gaung Persada Press. 